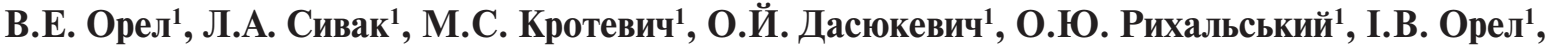
А.П. Бурлака 2 , С.М. Лукін ${ }^{2}$

\title{
Комбінований вплив вінорельбіну з наночастинками оксиду заліза й електромагнітного випромінювання на карциному легені Льюїс
}

\author{
${ }^{1}$ Національний інститут раку, Київ \\ ${ }^{2}$ Інститут експериментальної патології, онкології і радіобіології ім. Р.С. Кавецького НАН Украӥни, Київ \\ Одержано 1.03.2019 \\ Прийнято до друку 28.05.2019 \\ DOI: 10.32471/clinicaloncology.2663-466X.39.22663
}

\begin{abstract}
Мета. Вивчення можливості підвищення ефективності протипухлинної хіміотерапії вінорельбіном під дією комбінованого впливу наночастинок оксиду заліза та електромагнітного випромінювання на тварин з карциномою легені Льюїс. Об'єкт і методи. У дослідженнях використано 40 самців мишей лінії C57BI/6 масою тіла 18-20 г, наночастинки Fe $\mathrm{O}_{4}$ (Sigma-Aldrich) діаметром <50 нм і вінорельбін. Локалізоване електромагнітне опромінення (EO) пухлин проводили за допомогою апарата «Магнітерм" (Радмір, Україна) з вихідною потужністю 75 Вт. Тривалість сеансу ЕО становила 15 хв. Гістологічне типування новоутворень проведено з використанням рутинного забарвлення гематоксиліном і еозином та імуногістохімічного дослідження. Для дослідження редокс-стану пухлин та печінки вивчали спектри електронного парамагнітного резонансу, які реєстрували на комп'ютеризованому спектрометрі PE1307. Результати. Комплекс вінорельбіну та наночастинок 3 ЕО мав на $16 \%$ більший протипухлинний ефект і в 3,5 раза вищий індекс інгібування метастазів, ніж офіцинальний препарат. Результати гістологічних досліджень свідчать, що дія офіцинального вінорельбіну ініціювала збільшення некрозу пухлин на $34 \%$ проти контрольної групи. Комбінована дія вінорельбіну з наночастинками з/без ЕО збільшувала некроз карциноми легені Льюїс до 44\% у порівнянні із контрольною групою. Висновки. Комбінований вплив вінорельбіну з наночастинками та локального електромагнітного випромінювання на карциному легені Льюїс ініціював більший коефіцієнт гальмування росту пухлини, індекс інгібування метастазування та некроз при слабковираженій експресії бета-тубуліну, ніж офіцинального вінорельбіну. Гепатотоксичні ефекти при комбінованому лікуванні були менш вираженими, ніж під впливом офіцинального вінорельбіну.
\end{abstract}

Ключові слова: вінорельбін; наночастинки; карцинома легені Льюїс; метастази; $\beta$-тубулін; помірна гіпертермія; електромагнітне випромінювання.

\section{вступ}

За даними Міжнародної агенції SEER, 5-річна виживаність хворих на рак грудної залози всіх стадій становить близько $89,7 \%$. Кращий результат (5-річна виживаність - 98,7\%) відмічається у пацієнтів з локалізованим раком грудної залози. Але у 6\% хворих на рак грудної залози з метастазами цей показник становить лише 27\% [1]. В Україні у 2015 р. загальна кількість померлих від раку грудної залози досягла 5911 осіб [2], і тому актуальною $€$ проблема підвищення ефективності хіміотерапії хворих на рак цієї локалізації.

Один з протипухлинних препаратів, який зазвичай застосовують при лікуванні метастатичного раку грудної залози, є вінорельбін [3, 4]. Вінорельбін - напівсинтетичний хіміотерапевтичний лікарський препарат групи сполук, відомих як похідні алкалоїду барвінку рожевого, що були отримані з Catharanthus roseus, Vinca rosea, Lochnera rosea або Ammocallis rosea. Препарат належить до підгрупи антимікротубулярних агентів [5].

Розглянемо механізми дії вінорельбіну, які можливо було б використати для посилення його протипухлинного ефекту. Відомо, що алкалоїди Vinca індукують низку шляхів апоптотичної передачі сигналу. Ефект впливу вінорельбіну опосередковано через родину білків Bcl-2 і родину каспазних білків, які беруть участь у регуляції та індукції процесів апоптозу. Апоптотичний ефект вінорельбіну також пов'язаний з відповіддю на внутрішні сигнали мітохондріального апоптотичного механізму загибелі клітин [6].

Раніше було показано, що кожен з ряду $\alpha$-, $\beta$ - і $\gamma$-тубулінів має електричний заряд із дипольним моментом та орієнтацією за вектором електричного поля [7]. На підставі цього факту експериментально доведено, що електромагнітне поле може впливати на структуру та архітектоніку мікротрубочок [8]. Також показано, що імпульсні електричні поля можуть ініціювати загибель злоякісних клітин. Припускають, що ефект індукції апоптозу пухлинних клітин пов'язаний з дією $\mathrm{Ca}^{2+}$ залежних білків у їхній мітохондріальній мембрані [9].

Використання нанотехнологій у лікуванні раку дає можливість знищити пухлинні клітини електромагнітними полями, які можуть бути поглинені, та ініціювати механохімічні порушення [10], радіочастотну гіпертермію [11] чи локально стимулювати токсичний ефект, опосередкований продуктами оксидативного стресу за допомогою наночастинок (НЧ) оксиду заліза, у комплексі з протипухлинним препаратом [12]. У попередніх роботах встановлено, що радіочастотна гіпертермія, або абляція, у поєднанні з тривало циркулюючими ліпосомальними НЧ та вінорельбіном підвищувала ступінь локальної деструкції пухлини і виживаність тварин з аденокарциномою печінки Н22 [13].

Однак існує низка обмежень для радіочастотної гіпертермії з використанням НЧ: 1) терапія НЧ в інтервалі температур $43-70{ }^{\circ} \mathrm{C}$ може супроводжуватися утворенням хіміорезистентності за рахунок індукції білків теплового шоку; 2) температура $>45^{\circ} \mathrm{C}$ може зменшити перфузію пухлинної тканини; 3) неможливість лікування дисемінованого пухлинного процесу [14].

В якості перспективного напрямку подолання вищезазначених проблем може бути запропонована технологія, яка базується на використанні вінорельбіну з магнітними НЧ, що можуть спричиняти пошкодження білка тубуліну та ініціювати оксидативний стрес електромагнітним збудженням $[15,16]$.

Виходячи з цього, метою роботи є вивчення можливості підвищення ефективностіпротипухлинної хіміотерапії вінорельбіном за допомогою комбінованого впливу НЧ оксиду заліза та електромагнітного випромінювання на тварин з карциномою легеніЛьюїс.

\section{ЕКСПЕРИМЕНТАЛЬНІ МОДЕЛІ ТА МЕТОДИ}

У дослідженні використані самці мишей лінії С57Bl/6 (n=40, маса тіла 18-20 г) розведення віварію Національного інституту 
раку. Карциному легені Льюїс трансплантували тваринам шляхом ін'єкції $30 \%$ суспензії клітин $(0,4$ мл) у середовищі 199 у стегно, як описано в роботі [17]. Тварин розділили на 4 групи, по 10 мишей у кожній: 1-ша - контроль (без лікування); 2-га - офіцинальний вінорельбін; 3-тя - вінорельбін та електромагнітне опромінення (ЕО), 4-та - вінорельбін і магнітні НЧ + ЕО. Препарати в об’ємі 0,2 мл вводили внутрішньоочеревинно у таких концентраціях: вінорельбін 5 мг/кг або НЧ 3 мг/кг + вінорельбін 5 мг/кг. Розмір пухлини вимірювали за допомогою штангенциркуля. Через 25 днів після трансплантації пухлинних клітин досліджували кількість та об'єм метастатичного ураження у легенях $[18,19]$.

Використовували $\mathrm{HЧ} \mathrm{Fe}_{3} \mathrm{O}_{4}$ (Sigma-Aldrich) діаметром $<50$ нм і вінорельбін. Лікування починали на 2-й день після трансплантації пухлини, процедуру проводили п'ять разів через день. Для мінімізації впливу температури на магнітні властивості НЧ використовували метод індукційної помірної гіпертермії. Локалізоване ЕО пухлин проводили за допомогою експериментального прототипу апарата «Магнітерм» (Радмір, Україна) з вихідною потужністю 75 Вт. Для контролю температури усередині пухлин використовувався волоконно-оптичний термометр TM-4 (Радмір, Україна). Температура всередині пухлини не перевищувала $39,1{ }^{\circ} \mathrm{C}$ через 15 хв після початку сеансу ЕО. Тривалість сеансу ЕО становила 15 хв, який починали відразу після введення нанокомплексу на основі магнітних НЧ та вінорельбіну.

Усі дослідження на тваринах здійснювали згідно з нормами, встановленими Законом України № 3447-IV «Про захист тварин від жорстокого поводження», і нормами, прийнятими у Свропейській конвенції про захист хребетних тварин, що використовуються для дослідних та інших наукових цілей, від 18.03.1986 p.

Нелінійну кінетику росту пухлини оцінювали через фактор росту $\varphi$ за допомогою автокаталітичного рівняння та з використанням коефіцієнта гальмування:

$$
k=\varphi_{c} / \varphi_{e},
$$

де $\varphi_{\mathrm{c}}-$ фактор росту для контрольної групи; $\varphi_{\mathrm{e}}-$ фактор росту для досліджуваної групи [20].

Гістологічне типування новоутворень проведено з використанням рутинного забарвлення гематоксиліном і еозином та імуногістохімічного дослідження. Отриманий матеріал фіксували в забуференому $10 \%$ формаліні з pH 7,4 та ущільнювали у парафіні із застосуванням гістопроцесора Histos-5 («Milestone», Італія). Із парафінових блоків виготовляли гістологічні зрізи товщиною 5 мкм за допомогою мікротома Microm HM325 (ThermoScientific, Німеччина). Зрізи забарвлювали гематоксиліном і еозином для загальної оцінки пухлини. Імуногістохімічну реакцію проводили з антитілами до $\beta$-тубуліну (ThermoScientific, Німеччина) з використанням системи детекції EnVisionTM FLEX (Dako, Данія). Демаскування антигену проводили у цитратному буфері pH 6,0 при $95^{\circ} \mathrm{C}$. Первинні антитіла інкубували при кімнатній температурі 30 хв, вторинні - 20 хв. Зрізи дофарбовували гематоксиліном Gill. Для позитивного контролю використовували тканинні зразки з визначеною позитивною реактивністю, для негативного - проводили процедуру без застосування первинних антитіл. Отримані мікропрепарати фотографували і аналізували за допомогою мікроскопа OLYMPUS CX 41 із цифровою камерою і програмним забезпеченням QuickPHOTO MICRO 2.3 за стандартних умов. Відсоток некротичних зон у тканині пухлини оцінювали згідно з [21].

Для дослідження редокс-стану пухлин тапечінки вивчали спектри електронного парамагнітного резонансу (ЕПР), які реєстрували на комп'ютеризованому спектрометрі PE1307 в циліндричному резонаторі з типом коливань Н011 на частоті 9,15 $\pm 0,01$ ГГц. Потужність надвисокочастотного випромінювання становила 40 мВт. Використовували модуляцію магнітного поля замплітудою 10 Гс та частотою 100 кГц. Зразки тканин досліджували в парамагнітно чистому кварцовому Д'юарі за температури $-196^{\circ} \mathrm{C}$ (рідкого азоту). Об'єм проби становив 30 мкл. У пухлині досліджували інтенсивність триплетного сигналу ЕПР з g-фактором 2,007 - спектроскопічним маркером, що характеризує стан електронно-тран- спортного ланцюга (ЕТЛ) мітохондрій клітин пухлини. Зміни його інтенсивності характеризують рівень клітинної гіпоксії та ішемії. У печінці тварин-пухлиноносіїв досліджували зміни інтенсивності сигналу ЕПР при таких g-факторах: g-фактор 2,25, що характеризує активність низькоспінової форми цитохрому Р 450 у редокс-циклі системи детоксикації гепатоцитів; g-фактор 2,00 - рівень флавоубісеміхінонів в ЕТЛ мітохондрій гепатоцитів; g-фактор 1,94 - активність FeS-білка N2 типу в НАДН-убіхіноноксидоредуктазному комплексі ЕТЛ мітохондрій гепатоцитів.

Статистичний аналіз вірогідності отриманих даних проводили за допомогою $t$-критерію Стьюдента 3 попередньою перевіркою гіпотези про нормальний закон розподілу випадкової величини за критерієм Колмогорова - Смірнова. Для аналізу даних використовували пакет прикладних програм Statistica 10.0.

\section{РЕЗУЛЬТАТИ ТА ЇХ ОБГОВОРЕННЯ}

Результати аналізу нелінійної кінетики росту карциноми легені Льюїс з 7-ї по 24-ту добу після перещеплення пухлини наведено у табл. 1. Порівняльний аналіз свідчить, що комплекс вінорельбіну та НЧ з ЕО мав більший протипухлинний ефект, ніж офіцинальний препарат. За результатом розрахунку фактора росту, пухлини у 4-й групі тварин були меншими відповідно на 16 та $10 \%$ у порівнянні із групою тварин, які отримували лише вінорельбін та вінорельбін з ЕО. 3 результатів, наведених у табл. 2, можна зробити висновок, що мінімальний середній розмір метастазів та максимальний індекс інгібування метастазів були зафіксовані у 4-й групі тварин після комбінованого впливу комплексу вінорельбіну з НЧ оксиду заліза та ЕО. Середні розміри метастазів у 4-й групі тварин у порівнянні з 2-ю та 3-ю групами, що отримували лише вінорельбін та вінорельбін з ЕО, були відповідно в 3,5 та 1,7 раза меншими. У 2-й та 3-й групах тварин відзначалася лише тенденція до зменшення фактора росту пухлини.

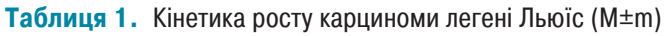

\begin{tabular}{clcc}
\hline Група & \multicolumn{1}{c}{ Вид впливу } & $\begin{array}{c}\text { Фактор рос- } \\
\text { ту пухлини } \\
\boldsymbol{\varphi}, \text { доба }\end{array}$ & $\begin{array}{c}\text { Коефіцієнт галь- } \\
\text { мування росту пух- } \\
\text { лини k, відн. од. }\end{array}$ \\
\hline 1 & Контроль (без впливу) & $0,34 \pm 0,01$ & 1,00 \\
2 & Офіцинальний вінорельбін & $0,33 \pm 0,01$ & 1,09 \\
3 & Вінорельбін + ЕО & $0,31 \pm 0,01$ & 1,10 \\
4 & Вінорельбін + НЧ + ЕО & $0,28 \pm 0,01^{*, \#}$ & 1,21 \\
\hline
\end{tabular}

*Статистично значущі відмінності порівняно з контролем, рівень значущості $p<0,05$.

\#Статистично значущі відмінності порівняно з групою 2, рівень значущості $\mathrm{p}<0,05$.

Таблиця 2. Метастазування тварин з карциномою легені Льюїс

\begin{tabular}{|c|c|c|c|}
\hline Група & Вид впливу & 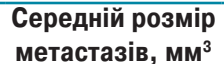 & $\begin{array}{c}\text { Індекс інгібуван- } \\
\text { ня метастазів }\end{array}$ \\
\hline 1 & Контроль (без впливу) & $0,73 \pm 0,13$ & - \\
\hline 2 & Офіцинальний вінорельбін & $1,42 \pm 0,40$ & - \\
\hline 3 & Вінорельбін + ЕО & $0,69 \pm 0,17$ & $6 \%$ \\
\hline 4 & Вінорельбін + НЧ + ЕО & $0,40 \pm 0,10^{*, \#}$ & $37 \%$ \\
\hline
\end{tabular}

*Статистично значущі відмінності порівняно з контролем, рівень значущості $p<0,05$.

\#Статистично значущі відмінності порівняно з групою 2, рівень значущості $p<0,05$.

Аналіз експериментально зареєстрованої нелінійної кінетики росту і процесів метастазування карциноми легені Льюїс підтримує раніше сформоване визначення нелінійних особливостей онкогенезу. А саме, при онкогенезі типовим $€$ посилення дезорганізації, що ініціює стохастичний процес на всіх рівнях біологічної ієрархічної організації організму. Проявом останнього можуть бути різні порушення у білках, кодованих «протоонкогенами» $\mathrm{i}$ «пухлинними супресорами», що призводить до порушення регуляції сигнальних шляхів, які контролюють клітинний цикл, апоптоз, генетичну стабільність, диференціацію та морфогенетичні реакції клітин [22].

При дослідженні гістологічних препаратів пухлинних тканин у тварин на 24-й день спостереження після перещеплення карциноми легені Льюїс відмічали такі характерні патомор- 
фологічні особливості та зміни експресії $\beta$-тубуліну. У контрольній 1-й групі (рис. 1) простежувалися поперечна смугастість тканин, зони некрозу до $21 \%$ та виражена експресія $\beta$-тубуліну. У 2-й групі (рис. 2) під впливом вінорельбіну зони некрозу становили до 55\% із середньовираженою експресією $\beta$-тубуліну. У 3-й групі (рис. 3) під впливом вінорельбіну та НЧ відмічалися клітини з дистрофічними та некробіотичними змінами, зони некрозу становили до 60-65\% та була середньовиражена експресія $\beta$-тубуліну. У 4-й групі (рис. 4) під впливом вінорельбіну та НЧ з ЕО візуалізувалися тканини з дистрофічними і некробіотичними змінами, некротичними зонами, які становили до $60-65 \%$, та була незначна експресія $\beta$-тубуліну.

Результати гістологічних досліджень свідчать, що дія офіцинального вінорельбіну ініціювала збільшення некрозу пухлин на 34\% у 2-й групі тварин проти 1-ї контрольної групи. Комбінована дія вінорельбіну з НЧ у 3-й та 4-й групах тварин збільшувала некроз карциноми легені Льюїс до 44\% у порівнянні 3 контрольною групою. При цьому, якщо в 1-й, 2-й та 3-й групах тварин відмічали виражену та середньовиражену експресію $\beta$-тубуліну, то в 4-й групі, де був найбільший коефіцієнт гальмування росту пухлини, цей показник слабковиражений Отримані дані підтверджують попередні відомості про те, що визначення експресії $\beta$-тубуліну може бути одним із незалежних предикторів прогресування злоякісної пухлини [23].

Механізм підвищення протипухлинного ефекту вінорельбіну при використанні ЕО можна інтерпретувати наступним чином: мікротрубочки клітин являють собою порожнисті циліндричні білкові полімери, які складаються з тубулінових $\alpha$ - та $\beta$-гетеродимерів. Димери спонтанно збираються поздовжньо для утворення протофіламентів у формі мікротрубочок, що призводить до спірального розташування гетеродимерів тубулінів. Маючи діаметр приблизно 25 нм, мікротрубочки утворюють жорстку, інтегральну структуру цитоскелета еукаріотичної клітини [24]. Відомо, що протипухлинна дія вінорельбіну заснована на інгібуванні полімеризації тубуліну. Препарат зв'язується переважно з мітотичними мікротрубочками та зумовлює мітотичне блокування і зрештою - апоптоз клітин [25]. Щодо тлумачення ефекту дії ЕО, то слід відмітити наступне. Електричний заряд та дипольний розподіл тубуліну у мікротрубочках може впливати на механізм поділу клітин [26]. Тому локальне електромагнітне випромінювання також може впливати на конформаційні зміни стану тубулінів [27]. Тобто, виходячи з вищезазначеного, зареєстроване більш суттєве зменшення вираженої експресії $\beta$-тубуліну в 3 -й та 4-й групах цілком логічно пов'язано з дією ЕО.

На рис. 5 наведено спектри ЕПР карциноми легені Льюїс та печінки тварин-пухлиноносіїв. У табл. 3 показано рівні змін інтенсивності сигналу ЕПР карциноми легені Льюїс щодо контролю, а в табл. 4 - зміни ЕПР-сигналу у печінці тварин-пухлиноносіїв. Отримані дані свідчать, що інтенсивність сигналу ЕПР карциноми легені Льюїс щодо контролю у 2-4-й групах тварин була нижчою, ніж у контрольній групі,
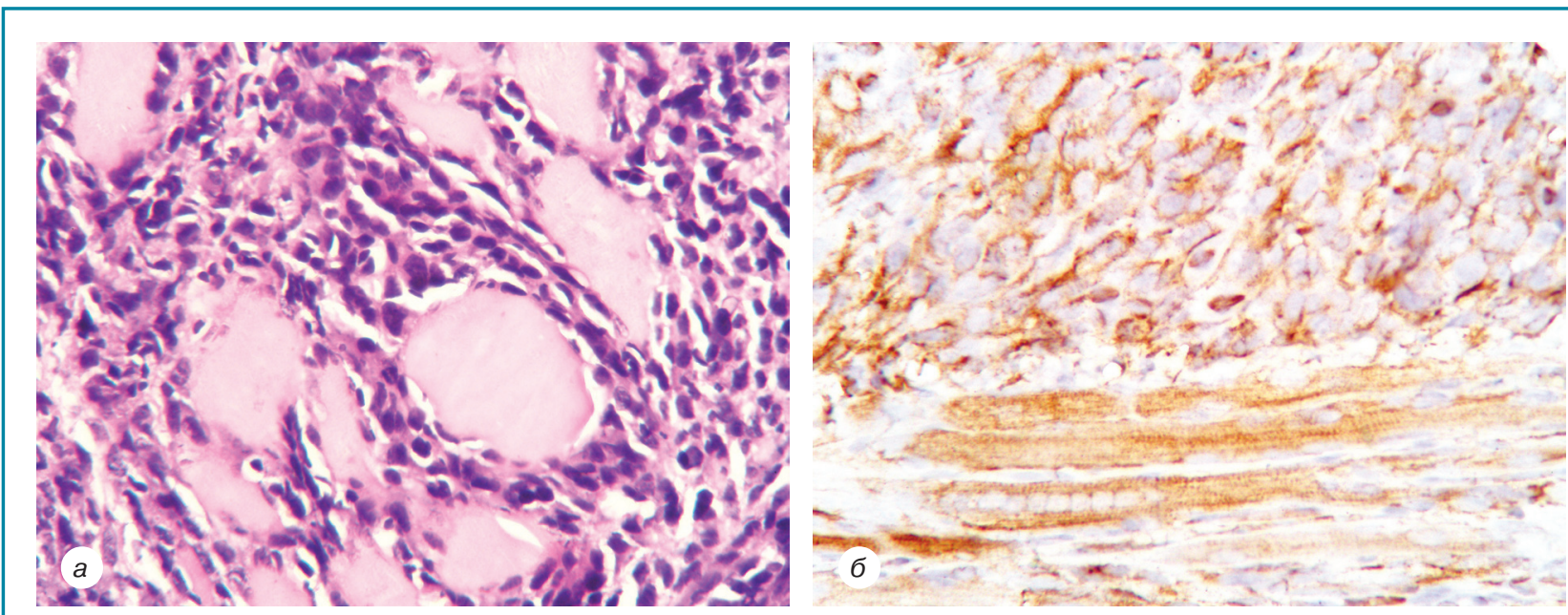

Рис. 1. Контрольна 1-ша група (без впливу): а - м'язові волокна, поперечний зріз карциноми легені Льюїс, забарвлення гематоксиліном та еозином. Зб. ×400; б - поздовжній зріз м'язових волокон, експресія $\beta$-тубуліну. Зб. ×400
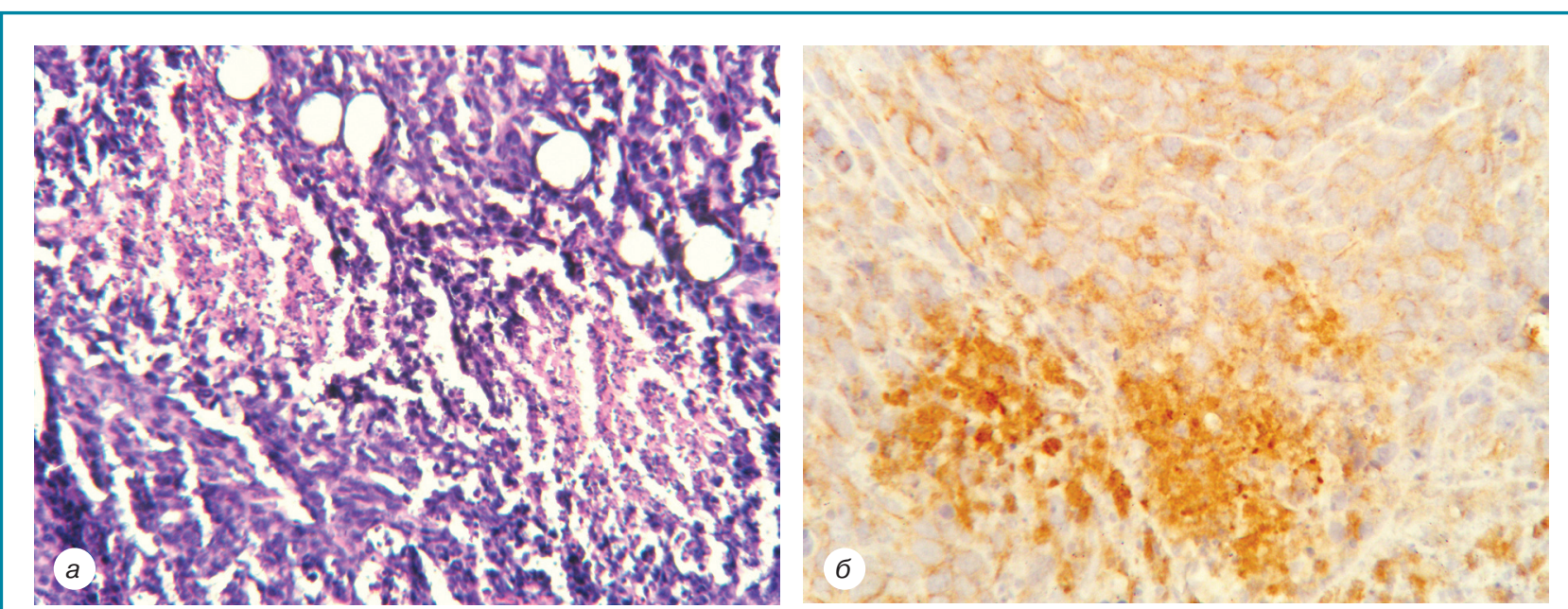

Рис. 2. 2-га група (вінорельбін): а - м'язові волокна, поперечний зріз карциноми легені Льюїс, забарвлення гематоксиліном та еозином. Зб. ×100; б — поздовжній зріз м'язових волокон, експресія $\beta$-тубуліну. Зб. ×200 


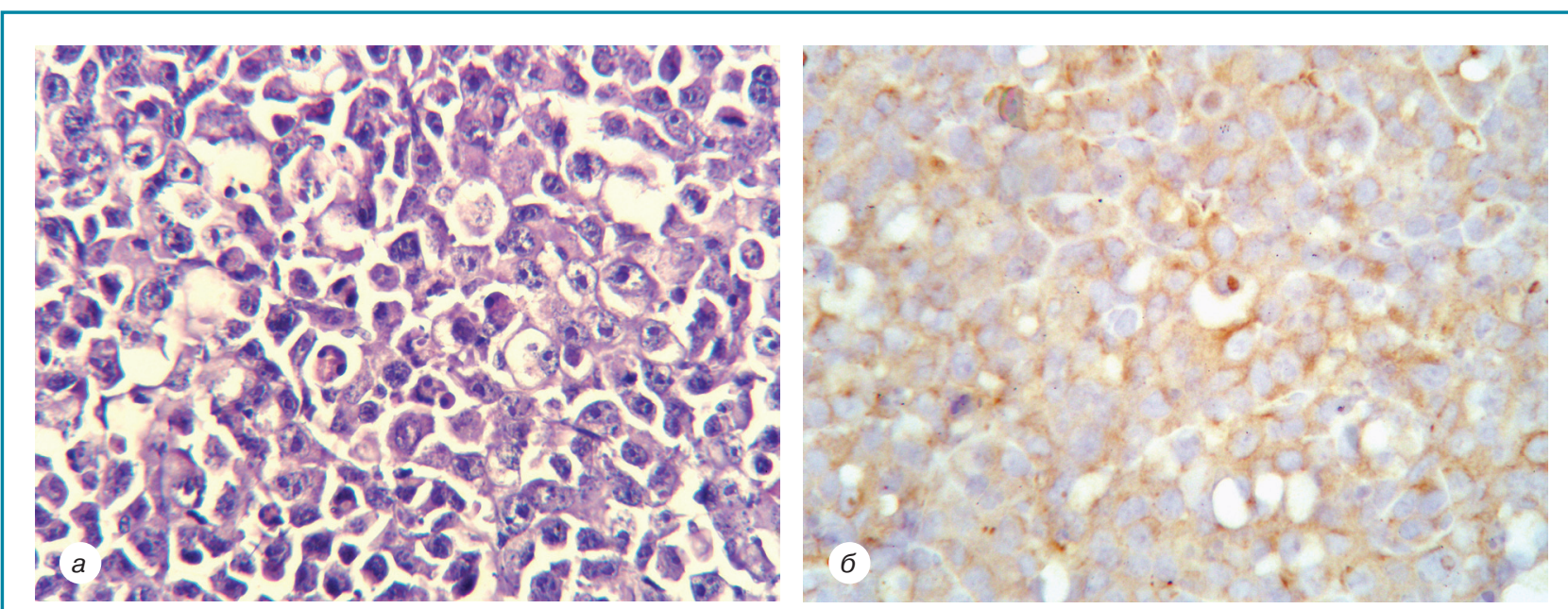

Рис. 3. 3-тя група (вінорельбін + ЕО): a - м'язові волокна, поперечний зріз карциноми легені Льюїс, забарвлення гематоксиліном та еозином. Зб. ×400; б - поздовжній зріз м'язових волокон, експресія $\beta$-тубуліну. Зб. ×400
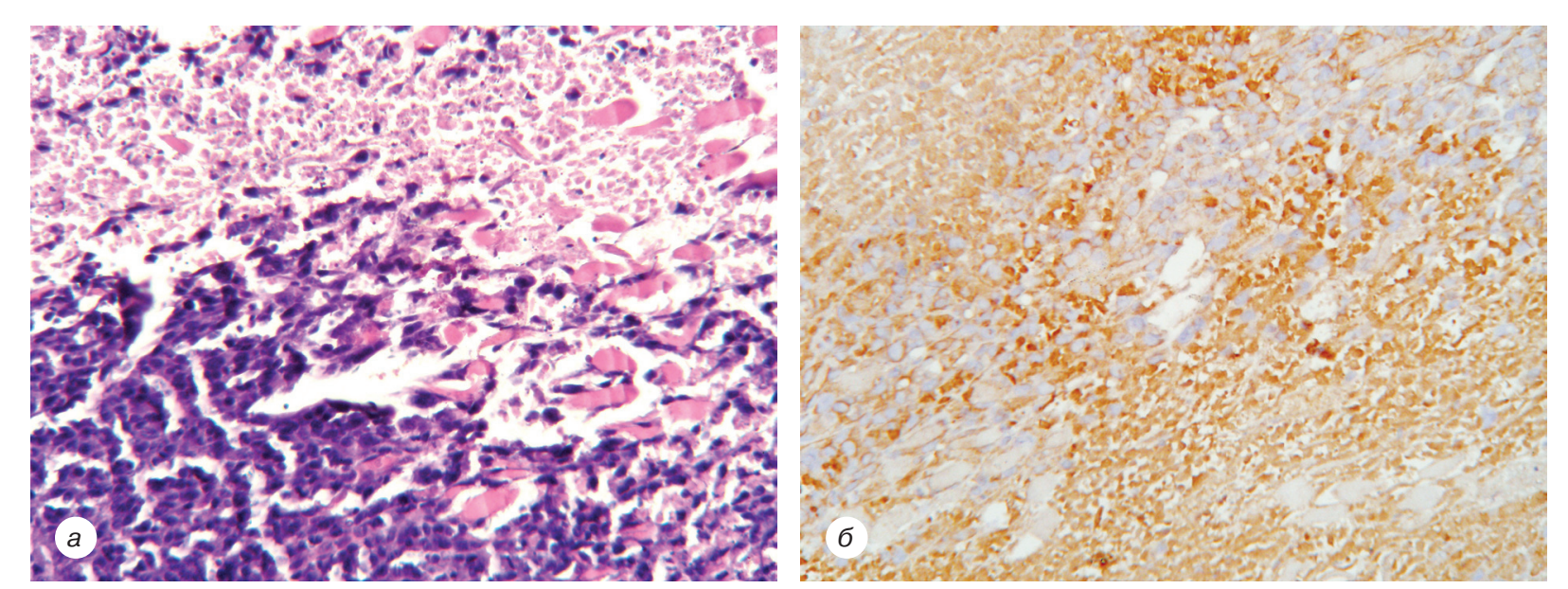

Рис. 4. 4-та група (вінорельбін + НЧ + ЕО): а - фрагменти м'язових волокон карциноми легені Льюїс, забарвлення гематоксиліном та еозином. Зб. ×200; б - поздовжній зріз м'язових волокон, експресія $\beta$-тубуліну. Зб. ×200

в середньому на 47\%. Аналіз зміни ЕПР-сигналу у печінці тварин-пухлиноносіїв виявив, що самостійна дія вінорельбіну спричинила суттєвіші зміни досліджуваного показника при різних g-факторах, ніж комбінований вплив препарату з ЕО чи НЧ + ЕО. Дані 3-ї та 4-ї груп достовірно не відрізнялися від показників 1-ї контрольної групи тварин та були нижчими за такі 2-ї групи в середньому на 43\% при g-факторі 2,25, на $39 \%$ - при g-факторі 2,00 та на 56\% - при g-факторі 1,94.

Таблиця 3. Інтенсивність сигналу ЕПР карциноми легені Льюїс

\begin{tabular}{clc}
\hline Група & \multicolumn{1}{c}{ Експеримент } & Інтенсивність спектра, відн. од. \\
\hline 1 & Контроль (без впливу) & $1,00 \pm 0,76$ \\
2 & Вінорельбін & $0,54 \pm 0,061^{\star}$ \\
3 & Вінорельбін + ЕО & $0,52 \pm 0,050^{\star}$ \\
4 & Вінорельбін + НЧ + ЕО & $0,53 \pm 0,049^{\star}$ \\
\hline
\end{tabular}

${ }^{*}$ Статистично значущі відмінності порівняно з контролем, рівень значущості $p<0,05$.

Таблиця. 4. Зміни ЕПР-сигналу у печінці тварин-пухлиноносіїв

\begin{tabular}{clccc}
\hline Група & \multirow{2}{*}{ Експеримент } & \multicolumn{3}{c}{ g-фактор, відн. од. } \\
\cline { 3 - 5 } тварин & & $\mathbf{2 , 2 5}$ & $\mathbf{2 , 0 0}$ & $\mathbf{1 , 9 4}$ \\
\hline 1 & Контроль (без впливу) & $0,35 \pm 0,03$ & $0,21 \pm 0,024$ & $0,47 \pm 0,053$ \\
2 & Вінорельбін & $0,59 \pm 0,06^{*}$ & $0,36 \pm 0,040^{*}$ & $1,07 \pm 0,93^{*}$ \\
3 & Вінорельбін + ЕО & $0,28 \pm 0,03^{\#}$ & $0,22 \pm 0,02^{*}$ & $0,52 \pm 0,05^{*}$ \\
4 & Вінорельбін + НЧ + EO & $0,40 \pm 0,04^{*}$ & $0,22 \pm 0,02^{*}$ & $0,45 \pm 0,038^{\#}$ \\
\hline
\end{tabular}

${ }^{*}$ Статистично значущі відмінності порівняно з контролем, рівень значущості $p<0,05$.

"Статистично значущі відмінності порівняно з групою 2, рівень значущосTi $p<0,05$.
Узагальнюючи результати досліджень спектрів ЕПР, слід зазначити, що інтенсивність сигналів ЕПР у 2-4-й групах тварин суттєво не відрізнялася та були нижчою, ніж у 1-й контрольній групі. Тобто кількість вільних радикалів (парамагнітних центрів) у досліджених пухлинах тварин 2-4-ї груп під впливом офіцинального вінорельбіну та комбінованого впливу препаратів з ЕО була майже однаковою. Що стосується зміни ЕПР-сигналу у печінці тварин-пухлиноносіїв, то слід відміти, що офіцинальний вінорельбін у тварин 2-ї групи зумовлював підвищення активності низькоспінової форми цитохрому Р450 у редокс-циклі системи детоксикації клітин печінки (g-фактор 2,25), рівня флавоубісеміхінонів в ЕТЛ мітохондрій гепатоцитів (g-фактор 2,00) та активності FeS-білка N2 типу в НАДН-убіхіноноксидоредуктазному комплексі ЕТЛ (g-фактор 1,94). У тварин-пухлиноносіїв 3-ї та 4-ї груп після комбінованого лікування з використанням нанокомплексу зазначені показники були нижчими. Якщо виходити з того, що досліджені показники відображають ступінь зміни оксидативного стресу [28], то можна припустити, що вплив вінорельбіну з НЧ оксиду заліза і локального електромагнітного випромінювання на карциному легені Льюїс спричинив менший гепатотоксичний ефект у тварин, ніж офіцинальний вінорельбін.

\section{ВисновКИ}

Комбінований вплив вінорельбіну з НЧ та локального електромагнітного випромінювання на карциному легені Льюї ініціював більший коефіцієнт гальмування росту пухлини, 


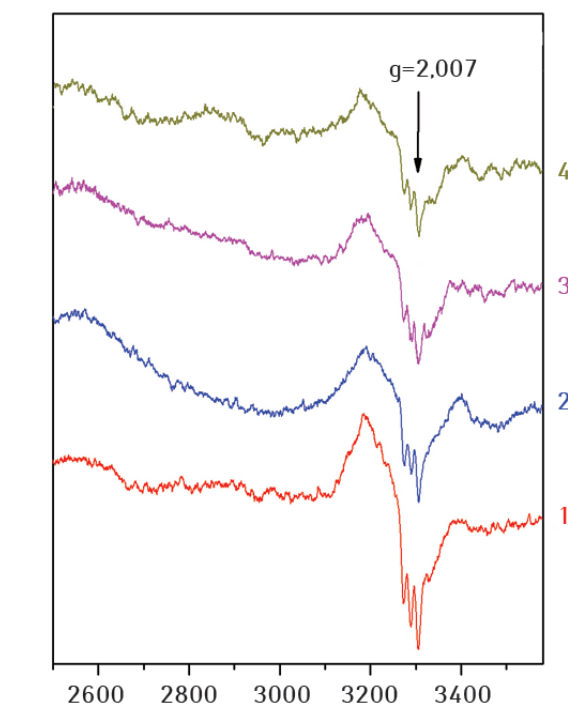

a

$\mathrm{H}$, Гc

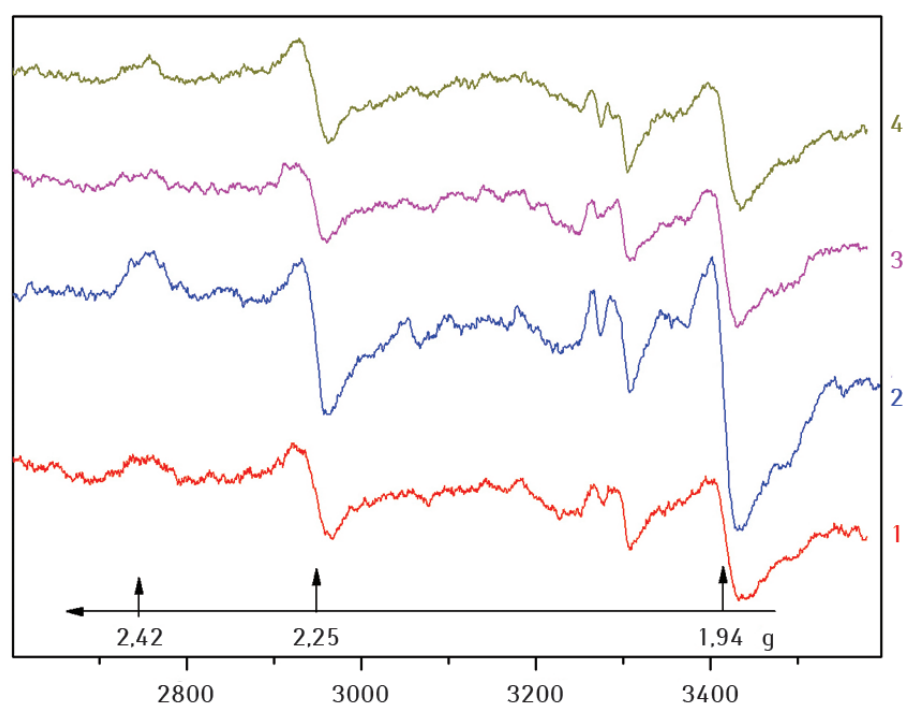

Н. Гс.

Рис. 5. Спектри ЕПР на 24-й день після перещеплення карциноми легені Льюїс (а) та печінки тварин-пухлиноносіїв (б): $1-$ контроль (без впливу); 2 - вінорельбін; 3 - вінорельбін + ЕО; 4 - вінорельбін + НЧ + ЕО. T= $77^{\circ} \mathrm{K}$

індекс інгібування метастазування та некроз при слабковираженій експресії $\beta$-тубуліну, ніж офіцинальний вінорельбін. Гепатотоксичні ефекти за результатами зміни ЕПР-сигналу у печінці при комбінованому лікуванні були менш вираженими, ніж під впливом офіцинального вінорельбіну.

\section{СПИСОК ВИКОРИСТАНОÏ ЛІТЕРАТУРИ}

1. The Surveillance, Epidemiology, and End Results (SEER) program of the U.S. National Cancer Institute, 18, 2008-2014.

2. Федоренко, З.П., Михайлович, Ю. Й., Гулак, Л. О., Горох, Є. Л., Рижов, А. Ю. Сумкіна, О. В., \& Куценко, Л.Б. (2014). Рак в Україні, 2015-2016. Захворюваність, смертність, показники діяльності онкологічної служби. Бюлетень Національного канцер-реєстру України, 18, 48

3. Furuse, K., Fukuoka, M., \& Kuba, M. (1996). Randomized study of vinorelbine versus vindezine in previously untreated stage IIIB or IV NSCLC. Annals of Oncology, 7(8), 815-820.

4. Jordan, M. A., \& Wilson, L. (2004). Microtubules as a target for anticancer drugs. Nature Reviews Cancer, 4(4), 253-265.

5. Chiu, W. H, Hai-Wen Chen, H., \& Su, W. C. (2012). Oral vinorelbine: a better choice for concurrent chemoradiotherapy in stage III non-small cell lung cancer. Journal of Solid Tumors, 2(6), 4-15.

6. Hayakawa, A., Kawamoto, Y., Nakajima, H., Sakai, J., Takasawa, R., Nakashima, ...Tanuma S. (2008). Bid truncation mediated by caspases-3 and -9 in vinorelbine-induced apoptosis. Apoptosis, 13(4), 523-531.

7. Tuszynski, J. A., Carpenter, E. J., Huzil, J. T., Malinski, W., Luchko T., \& Luduena, R. F. (2007). The evolution of the structure of tubulin and its potential consequences for the role and function of microtubules in cells and embryos. The International Journal of Developmental Biology, 50, 341-358.

8. Taghi, M., Gholamhosein, R., \& Saeed, R. Z. (2013). Effect of radio frequency waves of electromagnetic field on the tubulin. Recent Patents on Endocrine, Metabolic \& Immune Drug Discovery, 7(3), 252-256.

9. Beebe, S. J., Sain, N. M., \& Ren W. (2013). Induction of cell death mechanisms and apoptosis by nanosecond pulsed electric fields (nsPEFs). Cells, 2(1) 136-162.

10. Muroski, M. E., Morshed, R. A., Cheng, Yu., Vemulkar, T., Mansell, R., Han, Y. .. Lesniak, M.S. (2016). Controlled payload release by magnetic field triggered neural stem cell destruction for malignant glioma treatment. PLOS ONE, 11: e0145129.

11. Johannsen, M., Thiesen, B., Wust P. \& Jordan A. (2010). Magnetic nanoparticle hyperthermia for prostate cancer. International Journal of Hyperthermia, 26 $790-795$.

12. Orel, V., Shevchenko, A., Romanov A., Tselepi, M., Mitrelias, T., Barnes, C.H. Shchepotin, I. (2015). Magnetic properties and antitumor effect of nanocomplexes of iron oxide and doxorubicin. Nanomedicine, 11, 47-55.

13. Song Wang, Xing-Guo Mei, Nahum Goldberg, S., Muneeb Ahmed, Jung-Chieh Lee, Wei Gong ...WeiYang. (2016). Does thermosensitive liposomal vinorelbine improve end-point survival after percutaneous radiofrequency ablation of liver tumors in a mouse model? Radiology, 279(3), 762-772.

14. Thiesen B., \& Jordan A. (2008). Clinical applications of magnetic nanoparticles for hyperthermia. International Journal of Hyperthermia, 24, 467-474.

15. Yamada T., Egashira N., Takahisa M., Yano T., Yamauchi Y., Watanabe H., \& Oishi R. (2010). Role of oxidative stress in vinorelbine-induced vascular endothelial cell injury. Free Radical Biology and Medicine, 48(1), 120-127.

16. Orel, V. E., Tselepi, M., Mitrelias, T., Rykhalskyi, A., Romanov, A., Orel, V. B. ..Barnes, C. H. W. (2018). Nanomagnetic modulation of tumor redox state. Nanomedicine, 26, 1249-1256.

17. Matsuzaki, T., \& Yokokura, T. (1987). Inhibition of tumor metastasis of Lewis lung carcinoma in C57BL/6 mice by intrapleural administration of Lactobacillus casei. Cancer Immunology and Immunotherapy, 25, 100-104.
18. Gorelik, E., Segal, S., \& Feldman, M. (1980). Control of lung metastasis progression in mice: role of growth kinetics of $3 \mathrm{LL}$ Lewis lung carcinoma and host immune reactivity. Journal of the National Cancer Institute, 33(3), 1257-1264

19. Ritter, U., Scharff, P., \& Prylutska, S. V. (2011). Pristine $C_{60}$ fullerene S inhibit the rate of tumor growth and metastasis. Experimental Oncology, 33(3), 162-164.

20. Эмануэль, Н. М. (1977). Кинетика экспериментальных опухолевых процессов. Москва: Наука, 419 с.

21. Ramalho R. T., Aydos R. D., Schettert I., \& Cassino, P. C. (2014). Histopathological evaluation of tumor necrosis and volume after cyanogenic chemotherapy. Acta Cirúrgica Brasileira, 29(2), 38-42.

22. Coffey, D. S. (1998). Self-organization, complexity and chaos: the new biology for medicine. Nature Medicine, 4(8), 882-885.

23. Lebok, P., Öztürk, M., Heilenkötter, U., Jaenicke, F., Müller, V., PaluchowskiP. Quaas, A. (2016). High levels of class III $\beta$-tubulin expression are associated with aggressive tumor features in breast cancer. Oncology Letters, 11(3), 1987-1994.

24. Santelices, I. B., Friesen, D. E., Bell, C., Hough, C. M., Xiao, J., Kalra, A. .. Tuszynski, J. A. (2017). Response to alternating electric fields of tubulin dimers and microtubule ensembles in electrolytic solutions. Scientific Reports, 7(1), 9594.

25. Jordan, M. A., \& Wilson, L. (2004). Microtubules as a target for anticancer drugs. Nature Reviews Cancer, 4(4), 253-265.

26. Tuszyiski, J. A., Brown, J. A., Crawford, E., Carpenter, E. J. M., Nip, L. A., Dixon, J. M., \& Satarić, M. V. (2005). Molecular dynamics simulations of tubulin structure and calculations of electrostatic properties of microtubules. Mathematical and Computer Modelling, 41(10), 1055-1070.

27. Abdalla, E., Maroufi, B., Melgar, B. C., \& Sedra, M. B. (2001). Information transport by sine-Gordon solitons in microtubules. Physica A, Statistical Mechanics and its Applications, 301(1-4), 169-173.

28. Kopáni, M., Celec, P., Danisovic, L., Michalka, P., \& Biró, C. (2006) Oxidative stress and electron spin resonance. Clinica Chimica Acta, 364(1-2), 61-66.

Комбинированное влияние винорельбина

с наночастицами оксида железа

\section{и электромагнитного излучения на карциному} легкого Льюис

В.Э. Орел ${ }^{1}$, Л.А. Сивак ${ }^{1}$, М.С. Кротевич ${ }^{1}$, О.И. Дасюкевич ${ }^{1}$,

А.Ю. Рыхальский', И.В. Орел', А.П. Бурлака', С.Н. Лукин ${ }^{2}$

${ }^{1}$ Национальный институт рака, Киев

${ }^{2}$ Институт экспериментальной патологии, онкологии и радиобиологии им. Р.E. Кавецкого НАН Украины, Киев

Резюме. Цель. Изучение возможности повышения эффективности противоопухолевой химиотерапии винорельбином при комбинированном воздействии наночастиц оксида железа и электромагнитного излучения на животных с карциномой легкого Льюис. Объект и методы. Исследование проводили на 40 самцах мышей линии C57Bl/6 массой тела 18-20 г. Использовали наночастицы $\mathrm{Fe}_{3} \mathrm{O}_{4}$ (Sigma-Aldrich) диаметром $<50$ нм и винорельбин. Локализованное электромагнитное облучение (ЭО) проводили с помощью аппарата «Магнитерм» (Радмир, Украина) с выходной мощностью 75 Вт. Длительность сеанса ЭО составляла 15 мин. Гистологическое типирование новообразований проводили с использованием рутинной окраски гематоксилином и эозином, а также имму- 


\section{Оригінальні статті / Original Articles}

ногистохимического исследования. Для исследования редокссостояния опухоли и печени подопытных животных изучали спектры электронного парамагнитного резонанса, которые регистрировали на спектрометре РE1307. Результаты. Комплекс винорельбина и наночастиц с ЭО инициировал на 16\% больший противоопухолевый эффект и в 3,5 раза больший индекс ингибирования метастазов, чем официнальный препарат. Результаты гистологических исследований показали, что использование винорельбина приводило к увеличению некроза опухолей на $34 \%$ по сравнению с контрольной группой. Комбинированное действие винорельбина с наночастицами увеличивало некроз карциномы легкого Льюис до 44\% по сравнению с контрольной группой. Выводы. Комбинированное действие винорельбина с наночастицами и локальным электромагнитным излучением на карциному легкого Льюис инициировало больший коэффициент торможения роста опухоли, индекс ингибирования метастазов и некроз при слабовыраженной экспрессии бета-тубулина, чем официнальный винорельбин. Гепатотоксические эффекты при комбинированном лечении были менее выраженными по сравнению с действием официнального винорельбина.

Ключевые слова: винорельбин; наночастицы; карцинома легкого Льюис; метастазы; $\beta$-тубулин; умеренная гипертермия; электромагнитное излучение.

\section{Combined effect of the vinorelbine with iron oxide nanoparticles and electromagnetic radiation on the Lewis lung carcinoma \\ V.E. Orel ${ }^{1}$, L.A. Syvak ${ }^{1}$, M.S. Krotevych ${ }^{1}$, O.Y. Dasiukevych ${ }^{1}$, O.Y. Rykhalskyi ${ }^{1}$, I.V. Orel ${ }^{1}$, A.P. Burlaka ${ }^{2}$, S.M. Lukin ${ }^{2}$ \\ ${ }^{1}$ National Cancer Institute, Kyiv \\ ${ }^{2}$ R.E. Kavetsky Institute of Experimental Pathology, Oncology and Radiobiology, NAS of Ukraine, Kyiv}

Summary. Aim. The study of the possibility to increase the effectiveness of antitumor chemotherapy with vinorelbine during the combined effect of the iron oxide nanoparticles and electromagnetic radiation on the animals with Lewis lung carcinoma. Materials and methods. The study was made on 40 male $\mathrm{C} 57 \mathrm{Bl} / 6$ mice with body mass $18-20$ g. $\mathrm{Fe}_{3} \mathrm{O}_{4}$ (Sigma-Aldrich) nanoparticles with diameter $<50 \mathrm{~nm}$ and vinorelbine were used as parts of the antitumor drug. The apparatus «Magnetotherm» (Radmir, Ukraine) performed local electromagnetic irradiation (EI) of the tumor. The duration of the EI session was $15 \mathrm{~min}$. Histologic typing of tumors was provided using the routine coloration with hematoxylin and eosin and immunohistochemical research. To study the redox state of tumors and liver, electron paramagnetic resonance spectra were studied, which were recorded on a computerized spectrometer RE1307. Results. The complex of vinorelbine and nanoparticles with EI had a $16 \%$ greater antitumor effect, and up to 3.5 times higher metastatic inhibition index than the officinal drug. The results of histological studies indicate that the effect of officinal vinorelbine induced a tumors necrosis increase by $34 \%$ in comparison with the control group. The combined effect of vinorelbine with nanoparticles increased necrosis of the Lewis lung carcinoma to $44 \%$ in comparison with the control group. Conclusions. The combined effect of vinorelbine with nanoparticles and local electromagnetic radiation on the Lewis lung carcinoma initiated a higher tumor growth inhibition, a metastatic inhibition index and necrosis with a mild expression of tubulin beta than the officinal vinorelbine. Hepatotoxic effects in combined therapy were less pronounced than under the influence of officinal vinorelbine.

Key words: vinorelbine; nanoparticles; Lewis lung carcinoma; metastases; $\beta$-tubulin; moderate hyperthermia; electromagnetic radiation.

Адреса:

Орел Валерій Еммануїлович

03022, Київ, вул. Ломоносова, 33/43

Національний інститут раку

Тел.: (044) 257-60-68

E-mail:valeriiorel@gmail.com

Correspondence: Orel Valerii 33/43 Lomonosova Str., Kyiv 03022 National Cancer Institute Tel.: (044) 257-60-68 E-mail: valeriiorel@gmail.com 